\title{
Modified-atmosphere Packaging of Blueberry Fruit: Effect of Temperature on Package $\mathrm{O}_{2}$ and $\mathrm{CO}_{2}$
}

\author{
Randolph M. Beaudry, Arthur C. Cameron, Ahmad Shirazi ${ }^{1}$, and Diana L. Dostal-Lange ${ }^{2}$ \\ Department of Horticulture, Michigan State University, East Lansing, MI 48824-1325 “
}

Additional index words. Vaccinium corymbosum, steady-state oxygen, respiratory quotient, RQ breakpoint, anaerobiosis

\begin{abstract}
Highbush blueberry (Vaccinium corymbosum L. 'Bluecrop') fruit sealed in low-density polyethylene packages were incubated at $0,5,10,15,20$, or $25 \mathrm{C}$ until $\mathrm{O}_{2}$ and $\mathrm{CO}_{2}$ levels in the package reached a steady state. A range of steady-state $\mathrm{O}_{2}$ partial pressures $(1$ to $18 \mathrm{kPa}$ ) was created by placing a range of fruit weights within packages having a constant surface area and film thickness. The steady-state $\mathrm{O}_{2}$ partial pressure in packages containing the same weight of fruit decreased as temperature increased, indicating the respiratory rate rose more rapidly (i.e., had a greater sensitivity to temperature) than $\mathrm{O}_{2}$ transmission through the film. Steady-state $\mathrm{O}_{2}$ and $\mathrm{CO}_{2}$ partial pressures were used to calculate rates of $\mathrm{O}_{2}$ uptake. $\mathrm{CO}_{2}$ Production. and the respiratory quotient (RO). The effects of temperature and $\mathrm{O}_{2}$ partial pressure on $\mathrm{O}_{2}$ uptake and $\mathrm{CO}_{2}$ production and the $\mathrm{RQ}$ were characte zed. The steady-state $\mathrm{O}$, partial pressure at which the fruit began to exhibit anaerobic $\mathrm{CO}_{2}$ production (the $\mathrm{RQ}$ breakpoint) increased with increasing temperature, which implies that blueberry fruit can be stored at lower $\mathrm{O}_{2}$ partial pressures when stored at lower temperatures.
\end{abstract}

Studies using controlled-atmosphere (CA) storage techniques have indicated that shelf-life extension can be obtained for blueberry (Vaccinium spp.) fruit using combinations of elevated $\mathrm{CO}_{2}$ and reduced $\mathrm{O}_{2}$ in the storage environment (Ceponis and Cappellini, 1985; Smittle and Miller, 1988). CA storage of highbush blueberry fruit is now a commercial reality and current conditions range from 1.5 to $2.5 \mathrm{kpa} \mathrm{O}_{2}\left(1 \% \mathrm{O}_{2}=1.013 \mathrm{kPa}\right.$ $\mathrm{O}_{2}$ at $1 \mathrm{~atm}$ ) and 5 to $12 \mathrm{kPa} \mathrm{CO}_{2}$ at $0 \mathrm{C}$.

Present-day commercial techniques for packaging blueberry fruit do not modify $\mathrm{O}_{2}$ and $\mathrm{CO}_{2}$ to levels that would enhance storage. Modified-atmosphere packaging (MAP) has the potential to provide low $\mathrm{O}_{2} /$ high $\mathrm{CO}_{2}$ regimes similar to those of $\mathrm{CA}$ storage, but throughout the marketing chain. Ideally, a package should maintain the appropriate atmospheric composition over the range of temperatures commonly encountered between harvest and consumption. Poor temperature control, however, can cause package $\mathrm{O}_{2}$ levels to drop low enough to induce anaerobic respiration (Kader et al., 1989).

The purpose of our work was to investigate the influence of temperature on package $\mathrm{O}_{2}$ and $\mathrm{CO}_{2}$ partial pressures, on the rates of $\mathrm{O}_{2}$ uptake and $\mathrm{CO}_{2}$ production as functions of package $0_{2}$ partial pressure, and on the $\mathrm{O}_{2}$ partial pressure at the RQ breakpoint. Blueberry fruit were chosen for investigation due to their relatively long shelf life, their minimal changes in respiration associated with ripening, and their relative insensitivity to $\mathrm{CO}_{2}$ levels over the range of those expected to be encountered in the packaging system used.

\section{Materials and Methods}

\section{Plant material}

Fruit of 'Bluecrop' were hand-harvested into $46 \times 61 \times 20$ cm plastic field lugs $(\approx 8 \mathrm{~kg}$ of fruit) on 17 Aug. 1989 (second

\footnotetext{
Received for publication 29 July 1991. Accepted for publication 23 Jan. 1992. We acknowledge the Michigan Agricultural Experiment Station for its support of this research: The cost of publishing this paper was defrayed in part by the payment of page charges. Under postal regulations, this paper therefore must be hereby marked advertisement solely to indicate this fact.

'Present address: Dept. of Food Science and Human Nutrition, Michigan State Univ., East Lansing, MI 48824-1325.

'Present address: Dept. of Pomology, Univ. of California, Davis, CA 95616.
}

harvest of the season) in the West Olive area of Michigan. Fruit were transported immediately to East Lansing in ice chests. Fruit were held overnight at $5 \mathrm{C}$, sorted for obvious defects, and packaged the next morning.

\section{Film permeability}

The permeability of $0.00495 \mathrm{~cm}$ ( 2 roil) low-density polyethylene (LDPE) film to $\mathrm{O}_{2}$ and $\mathrm{CO}_{2}$ was determined three to 15 times for each of three random samples at temperatures ranging from 0 to $35 \mathrm{C}$ at $5 \mathrm{C}$ intervals. It was important to obtain our own permeability coefficients, since values supplied by manufacturers are often inaccurate. Film permeability values vary with each production run for a particular film type, and, in fact, we have commonly found a $10 \%$ to $15 \%$ variation in permeability along the length of a single roll of film.

The various temperatures were established by submersing a specially built aluminum permeability cell in a water bath (Lauda RC20; Brinkman Instrument Co., West Bury, N.Y.), and temperature $( \pm 0.1 \mathrm{C})$ was verified using mercury and thermocouple thermometers. The permeability cell contained two circular $(8$ $\mathrm{cm}$ diameter $\mathrm{x} 0.5 \mathrm{~cm}$ deep) $25-\mathrm{ml}$ chambers separated by the film sample, of which $50 \mathrm{~cm}^{2}$ was exposed to both chambers and sealed in place by an O-ring. The permeability cell was fitted with a $3.5-\mathrm{m}$ coil of $0.64-\mathrm{cm}$ (id.) copper tubing on the gas inlets to permit the inlet gas to reach the temperature of the water bath before entering the cell. Pure $\mathrm{O}_{2}$, pure $\mathrm{CO}_{2}$, or a mixture of both gases was introduced to one chamber of the cell and an $\mathrm{N}_{2}$ carrier gas was introduced to the other chamber. The rate of $\mathrm{O}_{2}$ and $\mathrm{CO}_{2}$ diffusion through the film was calculated from the steady-state partial pressure of the sample gases diffusing through the film and into the carrier gas stream. The partial pressure of $\mathrm{O}_{2}$ and/or $\mathrm{CO}_{2}$ in the carrier gas stream was determined using a sequential combination of $\mathrm{O}_{2}$ (Ametek S3A/II with a calcia-zirconia electrochemical detection cell; Ametek Co., Thermox Instrument Div., Pittsburgh) and $\mathrm{CO}_{2}$ (ADC 225MK3 analytical infrared gas analyzer; Analytical Development Co., Hertfordshire, England) analyzers. Gas concentrations in

Abbreviations: CA, controlled atmosphere; LDPE, low-density polyethylene; MAP, modified-atmosphere packaging; RQ, respiratory quotient. 
the carrier gas ranged from 2.5 to $150 \mu \mathrm{O}_{2} /$ liter and 12.5 to $750 \mu \mathrm{CO} /$ /liter, which were well within the limits of detectability. Concentrations were calculated relative to a certified standard gas mixture $\left(109 \mu \mathrm{O}_{2} /\right.$ liter and $94.3 \mu \mathrm{CO}_{2} /$ liter in $\mathrm{N}_{2}$ gas). Flow rates were maintained at $100 \mathrm{ml} \cdot \mathrm{min}^{-1}$ for all gases, and the chamber pressures were equalized and maintained at $\approx 6 \mathrm{~cm} \mathrm{H}_{2} \mathrm{O}$ above atmospheric.

Calculated concentrations were converted to partial pressures for determination of permeability coefficients. A best-fit equation of an Arrhenius plot of the data was used to determine permeability coefficients for packages at each storage temperature.

\section{Packaging}

Blueberry fruit were sealed into $10 \times 20-\mathrm{cm}\left(400 \mathrm{~cm}^{2}\right.$ total surface area) pouches comprised of 0.00495-cm-thick LDPE film (DOW Chemical Co., Midland, Mich.) for which $\mathrm{O}_{2}$ and $\mathrm{CO}_{2}$ permeability was measured as described above. Each package was equipped with a gas-sampling septum constructed of a short strip of electrical tape with a dab of DuPont Silicone II tub/tiling glue and sealant (Boylan-Pett, 1986). Fruit were weighed before being packaged, and weight per package was targeted at the following: $10,20,30,40,50,60,70,80,90,110,130$, and $150 \mathrm{~g}$. This range of 12 target weights was designed to generate a nearly continuous range of steady-state $\mathrm{O}_{2}$ and $\mathrm{CO}_{2}$ partial pressures within the package (Cameron et al., 1989). This range of fruit weights was placed at $0,5,10,15,20$, and $25 \mathrm{C}$ with four packages at each target weight/temperature combination.

\section{Steady-state $\mathrm{O}_{2}$ and $\mathrm{CO}_{2}$ levels and respiratory rates}

Package gas composition was determined daily by withdrawing a l-ml gas sample from the package with an insulin-type plastic syringe and analyzing the sample for $\mathrm{O}_{2}$ and $\mathrm{CO}_{2}$ using the above-noted $\mathrm{O}_{2}$ and $\mathrm{CO}_{2}$ analyzers connected in series with $\mathrm{N}_{2}$ as the carrier gas (flow rate $=150$ to $200 \mathrm{ml} \cdot \mathrm{min}^{-1}$. With this arrangement of detectors, $\mathrm{O}_{2}$ and $\mathrm{CO}_{2}$ concentrations could be determined for the same gas sample in $\approx 10 \mathrm{sec}$ and there was no need to correct for argon as in conventional gas chromatography. As before, gas concentrations were converted to partial pressures. The gas composition of individual packages was monitored until steady-state conditions were reached, at which time data were collected and analyzed. The time needed to achieve steady-state conditions increased as the storage temperature decreased and ranged from 2 days at $25 \mathrm{C}$ to $\approx 14$ days at 0 . No fungicide treatment was used; data were not taken from packages having obvious holes or containing moldy berries.

The steady-state $\mathrm{O}_{2}$ and $\mathrm{CO}_{2}$ partial pressures of the packages and the permeability data were combined to ascertain the rates of respiration using the following formulae:

$$
\begin{aligned}
\mathrm{RR}_{\mathrm{O}_{2}} & =\frac{\frac{\mathrm{P}_{\mathrm{O}_{2}} \cdot \mathrm{A}}{\mathrm{x}}\left[\left(\mathrm{O}_{2}\right)_{\mathrm{atm}}-\left(\mathrm{O}_{2}\right)_{\mathrm{pkg}}\right]}{\mathrm{W}} \\
\mathrm{RR}_{\mathrm{CO}_{2}}= & \frac{\frac{\mathrm{P}_{\mathrm{CO}_{2}} \cdot \mathrm{A}}{\mathrm{x}}\left[\left(\mathrm{CO}_{2}\right)_{\mathrm{pkg}}-\left(\mathrm{CO}_{2}\right)_{\mathrm{atm}}\right]}{\mathrm{W}},
\end{aligned}
$$

where $\mathrm{RRO}_{2}$ and $\mathrm{RRCO}_{2}$ are the rates of $\mathrm{O}_{2}$ uptake and $\mathrm{CO}_{2}$ production $\left(\mathrm{mmol} \cdot \mathrm{kg}^{-1} \cdot \mathrm{h}^{-1}\right)$, respectively; $\mathrm{PO}_{2}$ and $\mathrm{PCO}_{2}$ are mea- sured $\mathrm{O}_{2}$ and $\mathrm{CO}_{2}$ permeability coefficients $\left(\mathrm{mmol} \cdot \mathrm{cm}^{-1}\right.$ per $\mathrm{cm}^{2}$ per hour per $\mathrm{kPa}$ ), respectively, for our LDPE at the storage temperature; $A$ is film area $\left(\mathrm{cm}^{2}\right) ; \mathrm{x}$ is film thickness $(\mathrm{cm}) ;\left(\mathrm{O}_{2}\right), \mathrm{m}$ and $\left(\mathrm{O}_{2}\right)$ pkg are atmospheric and package partial pressures of $\mathrm{O}_{2}$ $(\mathrm{kPa})$, respectively; $\left(\mathrm{CO}_{2}\right)_{\mathrm{pkg}}$ and $\left(\mathrm{CO}_{2}\right)_{\text {atm }}$ are the package and atmospheric $\mathrm{CO}_{2}$ partial pressures $(\mathrm{kPa})$, respectively, and $\mathrm{W}$ is fruit weight $(\mathrm{kg})$. The RQ was calculated as $\mathrm{RRCO}_{2}$, divided by $\mathrm{RRO}_{2}$. Data were plotted and analyzed using a computer nonlinear regression analysis package (Eisensmith, 1987).

\section{Results}

\section{Film permeability}

$\mathrm{PO}_{2}$ and $\mathrm{Pco}_{2}$ increased exponentially with increasing temperature (Fig. 1). An Arrhenius plot of the data (Fig. 1, inset) indicated that the natural log of the permeability coefficient for both gases depended linearly on the reciprocal of temperature ${ }^{\circ} \mathrm{K}$ ), and the relationship could be expressed with the equation:

$$
\ln \left(\mathrm{P}_{\mathrm{i}}\right)=\frac{\mathrm{Ea}}{\mathrm{RT}}+\ln (\mathrm{A}),
$$

where $\mathrm{Pi}$ is $\mathrm{PO}_{2}$ or $\mathrm{PCO}_{2}$; Ea is the energy of activation of $\mathrm{O}_{2}$ or $\mathrm{CO}_{2}$ permeation $\left(\mathrm{kJ} \cdot \mathrm{mol}^{-1}\right)$; and $\mathrm{R}$ is the gas constant $(0.0083144$ $\mathrm{kJ} / \mathrm{mol}$ per $\left.{ }^{\circ} \mathrm{K}\right)$. The slope of the fitted line was $\mathrm{Ea} / \mathrm{R}$. Average Ea values were $39.72 \mathrm{~kJ} \cdot \mathrm{mol}^{-1}$ for $\mathrm{O}_{2}(\mathrm{SD}=1.3)$ and 35.53 $\mathrm{kJ} \cdot \mathrm{mol}^{-1}$ for $\mathrm{CO}^{2}(\mathrm{SD}=0.31)$. Average values for the $\mathrm{Y}$ intercept $[\mathrm{in}(\mathrm{A})]$ were 5.42 for $\mathrm{O}_{2}(\mathrm{SD}=0.13)$ and 5.22 for $\mathrm{CO}_{2}$ $(\mathrm{SD}=0.027)$. The coefficient of determination $\left(\mathrm{r}^{2}\right)$ values for individual Es/ $\mathrm{R}$ determinations ranged from 0.9951 to 0.9999 for $\mathrm{O}_{2}$ and 0.9984 to 0.9999 for $\mathrm{CO}_{2}$. Values obtained for $\mathrm{Ea}$ and permeability coefficients are similar to published values for LDPE (Yasuda and Stannett, 1975). Equations for predicting $\mathrm{PO}_{2}$ and $\mathrm{PCO}_{2}$ for the film at any $\mathrm{T}$ are as follows:

$$
\begin{array}{r}
\mathrm{P}_{\mathrm{O}_{2}}=0.2269 \times \exp (-4777 / \mathrm{T}) \mathrm{mmol} \cdot \mathrm{cm}^{-1} \text { per } \mathrm{cm}^{2} \\
\text { per hour per } \mathrm{kPa}
\end{array}
$$

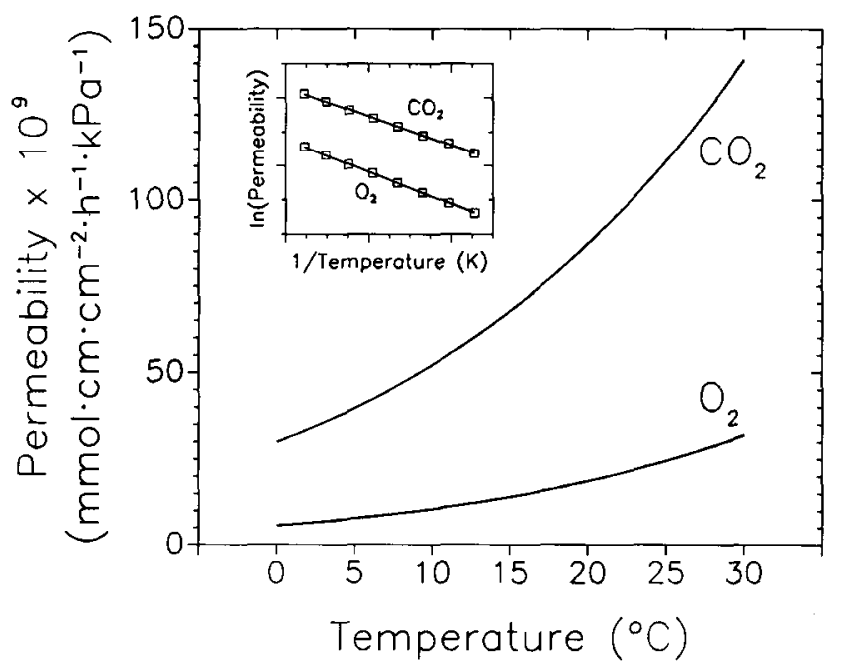

Fig. 1. Effect of temperature on film permeability constants for $\mathrm{O}_{2}$ and $\mathrm{CO}_{2}\left(\mathrm{PO}_{2}\right.$ and $\mathrm{PcO}_{2}$, respectively) for 0.00495 -cm-thick LDPE film used in packaging experiments. Inset: Arrhenius plot of $\mathrm{O}_{2}$ and $\mathrm{CO}_{2}$ permeability for typical film sample. 
where $\mathrm{T}$ is temperature in ${ }^{\circ} \mathrm{K}$. Values of $\mathrm{Po}_{2} \cdot \mathrm{A} / \mathrm{x}$ and $\mathrm{P}_{\mathrm{CO}_{2}} \cdot \mathrm{A} / \mathrm{x}$ were generated using Eq. [4] and [5] and substituting $400 \mathrm{~cm}^{2}$ and $0.00495 \mathrm{~cm}$ for A and $\mathrm{x}$, respectively (Table 1). These values and weight vs. $\mathrm{O}_{2}$ and $\mathrm{CO}_{2}$ data from Fig. 2 can be substituted directly into Eq. [1] and [2] for calculation of $\mathrm{RRO}_{2}$ and $\mathrm{RRCO}_{2}$ for any one of the six temperatures studied. $\mathrm{PCO}_{2}$ was $\approx 4.5$ to 5 times $\mathrm{PO}_{2}$ for this film over the temperature range (Table 1).

\section{Steady-state $\mathrm{O}_{2}$ and $\mathrm{CO}_{2}$ levels and respiratory rates}

Increasing the weight of fruit in the package caused a decrease in steady-state $\mathrm{O}_{2}$ at each temperature (Fig. 2). As the temperature increased, steady-state $0_{2}$ tended to decrease for a given package fruit weight (Fig. 3). The data describing the relation-

Table 1. Whole package $\mathrm{O}_{2}$ and $\mathrm{CO}_{2}$ permeabilities $(\mathrm{PO} 2 \cdot \mathrm{A} / \mathrm{x}$ and $\mathrm{PCO}_{2} \cdot \mathrm{A} / \mathrm{x}$, respectively) for the packages used in these experiments at $0,5,10, .15,20$, and $25 \mathrm{C}$. Values were generated using Eqs. [4] and [5] for packages having a surface area (A) of $400 \mathrm{~cm}^{2}$ and film thickness (x) of $0.00495 \mathrm{~cm} . \mathrm{PO}_{2}$ and $\mathrm{PCO}_{2}$ are LDPE film permeability constants for $\mathrm{O}_{2}$ and $\mathrm{CO}_{2}$, respectively. Eq. [4]: $\mathrm{PO}_{2}=0.2269$ $\times \exp (-4777 / \mathrm{T}) \quad \mathrm{mmol} \cdot \mathrm{cm}^{-1}$ per $\mathrm{cm}^{2}$ per hour per $\mathrm{kPa}$; and $\mathrm{Eq}$. [5]: $\mathrm{PCO}_{2}=0.1858 \times \exp (-4273 / \mathrm{T}) \mathrm{mmol} \cdot \mathrm{cm}^{-1}$ per $\mathrm{cm}^{2}$ per hour per $\mathrm{kPa}$.

\begin{tabular}{cccc}
\hline \hline $\begin{array}{c}\text { Temp } \\
\left({ }^{\circ} \mathrm{C}\right)\end{array}$ & $\mathrm{PO}_{2} \cdot \mathrm{A} / \mathrm{x}$ & $\mathrm{PCO}_{2} \cdot \mathrm{A} / \mathrm{x}$ & \\
\hline 0 & $4.612 \times 10^{-4}$ & $2.393 \times 10^{-3}$ & $\mathrm{PC}_{2} / \mathrm{PO}_{2}$ \\
5 & $6.318 \times 10^{-4}$ & $3.171 \times 10^{-3}$ & 5.19 \\
10 & $8.560 \times 10^{-4}$ & $4.160 \times 10^{-3}$ & 5.01 \\
15 & $11.47 \times 10^{-4}$ & $5.407 \times 10^{-3}$ & 4.86 \\
20 & $15.23 \times 10^{-4}$ & $6.965 \times 10^{-3}$ & 4.71 \\
25 & $20.02 \times 10^{-4}$ & $8.896 \times 10^{-3}$ & 4.57 \\
\hline
\end{tabular}

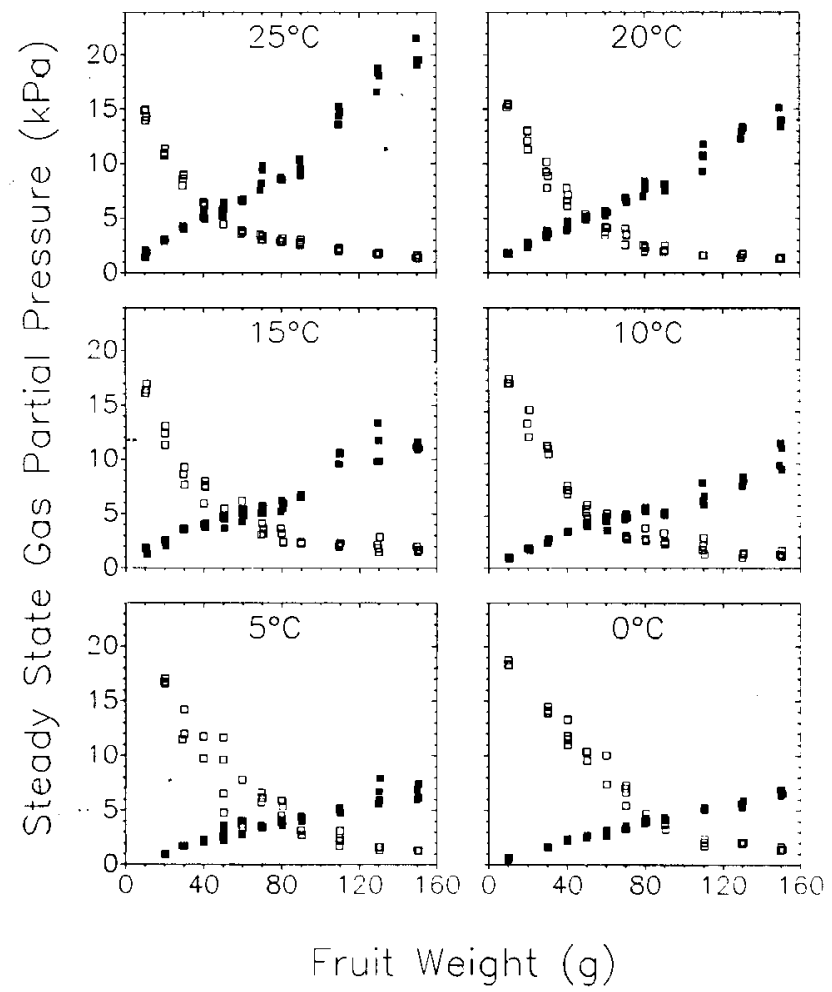

Fig. 2. Effect of blueberry fruit weight on steady-state $\mathrm{O}_{2}$ (open symbols) and $\mathrm{CO}_{2}$ (closed symbols) partial pressures in 400-cm, $0.00495-$ cm-thick LDPE sealed packages held at $0,5,10,15,20$, or $25 \mathrm{C}$.

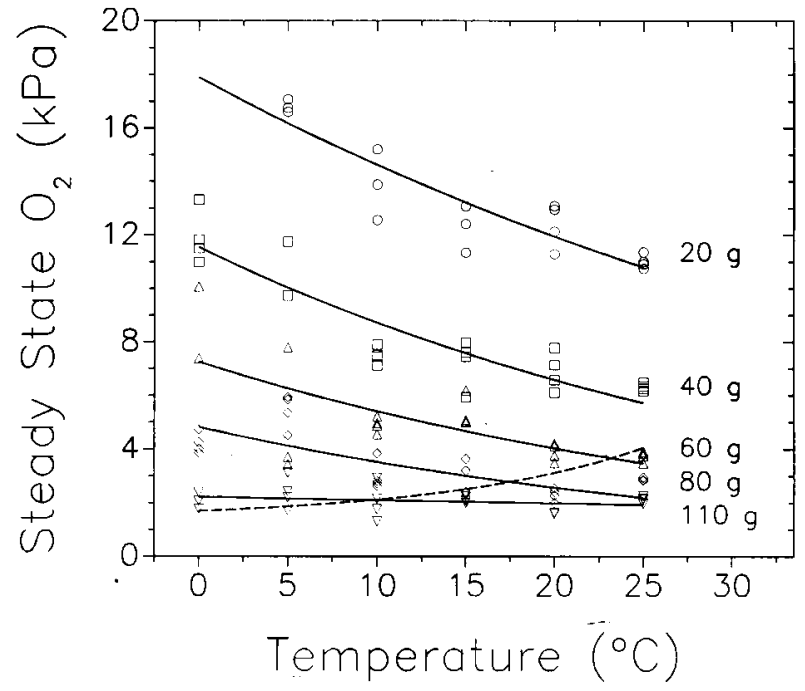

Fig. 3. Effect of temperature on: 1) steady-state $0_{2}$ levels for various weights of blueberry fruit sealed in $400-\mathrm{cm}^{2}, 0.00495$-cm-thick LDPE packages (solid lines) containing 20,40,60,80, or $110 \mathrm{~g}$ of fruit; and 2) the estimated lower $\mathrm{O}_{2}$ limit for blueberry fruit (dashed line) based on Fig. 6. See Table 2 for equations describing curves.

Table 2. General equation (Eq. [2]) and values of weight-dependent constants describing the relationship between temperature $\left({ }^{\circ} \mathrm{C}\right)$ and steady-state $\mathrm{O}_{2}$ partial pressures $(\mathrm{kPa})$ for various weights of blueberry fruit sealed in LDPE pouches and stored at six temperatures. Eq. [2]: $\left(\mathrm{O}_{2}\right)_{\mathrm{pkg}}=\mathrm{x}_{1} \cdot \exp \left(-\mathrm{x}_{2} \cdot \mathrm{T}\right)$.

\begin{tabular}{cccc}
\hline \hline Package wt $(\mathrm{g})$ & $\mathrm{x}_{1}$ & $\mathrm{x}_{2}$ & $R^{2}$ \\
\hline 20 & 17.89 & $2.02 \times 10^{-2}$ & 0.82 \\
40 & 11.54 & $2.81 \times 10^{-2}$ & 0.82 \\
60 & 7.248 & $2.94 \times 10^{-2}$ & 0.48 \\
80 & 4.816 & $3.14 \times 10^{-2}$ & 0.52 \\
110 & 2.218 & $5.66 \times 10^{-3}$ & 0.05 \\
\hline
\end{tabular}

ship between fruit temperature and package $0_{2}$ were fitted empirically with the simple exponential equation:

$$
\left(\mathrm{O}_{2}\right)_{\mathrm{pkg}}=\mathrm{x}_{1} \cdot \exp \left(\mathrm{x}_{2} \cdot \mathrm{T}\right) \text {, }
$$

where $\left(\mathrm{O}_{2}\right)_{\mathrm{pkg}}$ is the steady-state $\mathrm{O}_{2}$ partial pressure and $\mathrm{T}$ is temperature in ${ }^{\circ} \mathrm{C}$. Values for weight-dependent constants $\mathrm{xl}$ and $\mathrm{x}_{2}$ and the $R^{2}$ of the fit are listed in Table 2.

The measured $\mathrm{O}_{2}$ and $\mathrm{CO}_{2}$ gradients across the film were used to calculate steady-state diffusion rates for both gases through the film, and the respiration rates were calculated (assuming diffusion rates through the package were equal to $\mathrm{O}_{2}$ and $\mathrm{CO}_{2}$ fluxes for the respiratory processes) on a per-package weight basis. For each temperature, the relationship between $\mathrm{O}_{2}$ uptake and steady-state $\mathrm{O}_{2}$ (Fig. 4) was empirically fitted with the exponential equation:

$$
\mathrm{RRO}_{2},=\mathrm{b}_{1} \cdot\left\{1-\exp \left[-\mathrm{b}_{2} \cdot\left(\mathrm{O}_{2}\right)_{\mathrm{pkg}}\right\}^{\mathrm{b3}}\right.
$$

(Cameron, 1990; Cameron et al., 1989), where $\mathrm{RRo}_{2}$ is the rate of $\mathrm{O}_{2}$ uptake $\left(\mathrm{mmol} \cdot \mathrm{kg}^{-1} \cdot \mathrm{h}^{-1}\right)$ and $\left(\mathrm{O}_{2}\right)_{\mathrm{pkg}}$ is the steady-state $\mathrm{O}_{2}$ partial pressure $(\mathrm{kPa})$. Values for constants $\mathrm{b}_{1}, \mathrm{~b}_{2}$, and $\mathrm{b}_{3}$ and the $R^{2}$ of the fit at each temperature are listed in Table 3.

Oxygen consumption decreased in response to decreasing temperature and decreasing steady-state $\mathrm{O}_{2}$ (Fig. 4). Interestingly, the shape of the $\mathrm{O}_{2}$-dependent respiratory curves changed with temperature. At the higher temperatures, $\mathrm{O}_{2}$ uptake did not appear to approach saturation even at the highest levels of steady- 


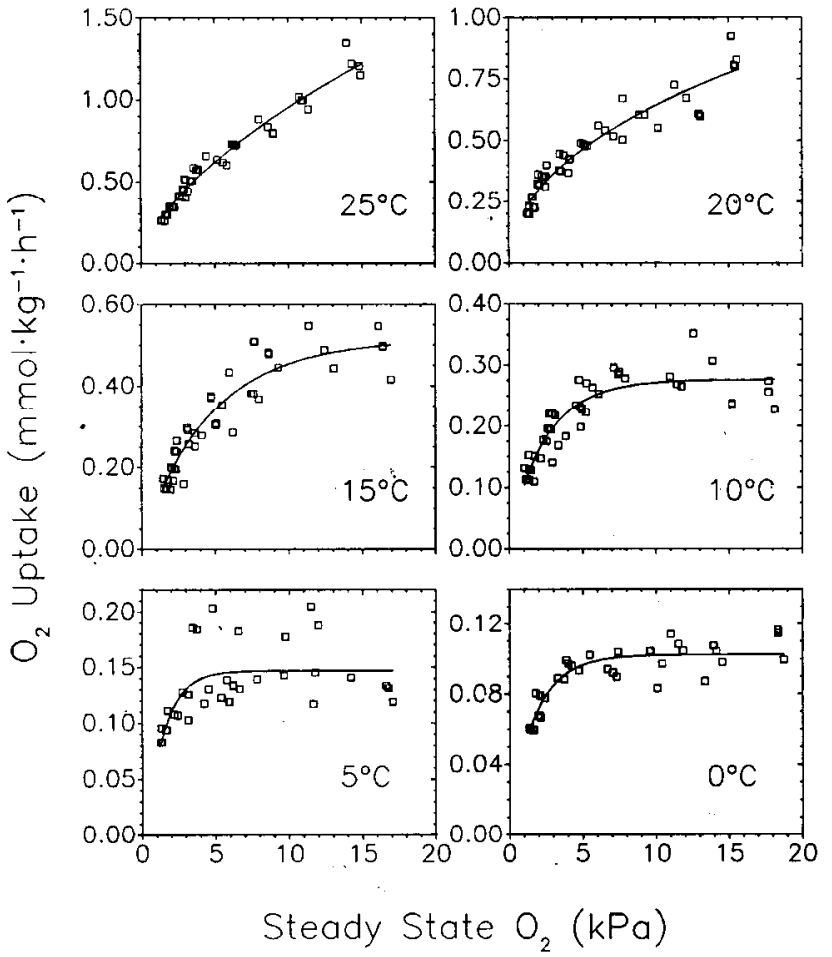

Fig.4. Interdependent effects of steady-state $\mathrm{O}_{2}$ partial pressure and storage temperature on the calculated rate of $\mathrm{O}_{2}$ uptake. of blueberry fruit in sealed LDPE packages. See Table 4 for equations describing curves.

Table 3. General equation (Eq. [7]) and values of temperature-dependent constants describing the relationship between steady-state $\mathrm{O}_{2}$ partial pressures $(\mathrm{kPa})$ and $\mathrm{O}_{2}$ uptake $\left(\mathrm{mmol} \cdot \mathrm{kg}^{-1} \cdot \mathrm{h}^{-1}\right)$ for blueberry fruit sealed in LDPE Douches and stored at various temperatures. Eq. [7]: $\mathrm{RRO}_{2}=\mathrm{b}_{1} \cdot\left\{1-\exp \left[-\mathrm{b}_{2} \cdot\left(\mathrm{O}_{2}\right)_{\mathrm{pkg}}\right]\right\}^{\mathrm{b3}}$.

\begin{tabular}{lllll}
\hline \hline Temp $\left({ }^{\circ} \mathrm{C}\right)$ & $\mathrm{b}_{1}$ & \multicolumn{1}{c}{$\mathrm{b}_{\mathbf{2}}$} & $\mathrm{b}_{3}$ & $R^{2}$ \\
\hline 25 & 4.561 & $9.111 \times \mathbf{1 0}^{-3}$ & 0.6428 & $\mathbf{0 . 9 7}$ \\
20 & 1.871 & $1.235 \times \mathbf{1 0}^{-2}$ & 0.4968 & $\mathbf{0 . 9 2}$ \\
15 & 0.514 & $2.067 \times \mathbf{1 0}^{-1}$ & 0.9205 & $\mathbf{0 . 8 8}$ \\
10 & 0.2765 & $3.829 \times \mathbf{1 0}^{-1}$ & 0.8795 & $\mathbf{0 . 8 1}$ \\
5 & 0.1469 & $8.461 \times \mathbf{1 0}^{-1}$ & 1.401 & 0.48 \\
0 & 0.1024 & $5.427 \times 10^{-1}$ & 0.8506 & $\mathbf{0 . 8 0}$ \\
\hline
\end{tabular}

state $\mathrm{O}_{2}$ generated. As temperature declined, however, $\mathrm{O}_{2}$ uptake showed signs of saturation at ever decreasing $\mathrm{O}_{2}$ partial pressures. As a result of this phenomenon, fruit were found to be more sensitive to restricted $\mathrm{O}_{2}$ availability as temperatures increased. For instance, at $0 \mathrm{C}$ respiration at $1.5 \mathrm{kPa} \mathrm{O}_{2}$ was about half that at $16 \mathrm{kPa} \mathrm{O}_{2}$, while at $25 \mathrm{C}$, respiration at 1.5 $\mathrm{kPa} \mathrm{O}_{2}$ was about one-fifth that at $16 \mathrm{kpa}$ (Fig. 4).

Carbon dioxide production depended on temperature and $\mathrm{O}_{2}$ partial pressure (Fig. 5). Carbon dioxide production declined with decreasing temperature and, in general, with decreasing $\mathrm{O}_{2}$ levels. At the lower $\mathrm{O}_{2}$ partial pressures, however, the $\mathrm{CO}_{2}$ respiratory rate did not approach zero, and at some temperatures, $\mathrm{CO}_{2}$ production increased as the $\mathrm{O}_{2}$ partial pressures decreased. The rate of $\mathrm{CO}_{2}$ production was not fitted with an equation due to the difficulties presented by the inflection in the data occurring at the lower $\mathrm{O}_{2}$ levels.

The RQ depended on both steady-state $\mathrm{O}_{2}$ and storage temperature (Fig. 6). At all temperatures except $0 \mathrm{C}$, the RQ increased as the steady-state $\mathrm{O}_{2}$ approached zero; however, the RQ breakpoint occurred at higher levels of $\mathrm{O}_{2}$ as temperature

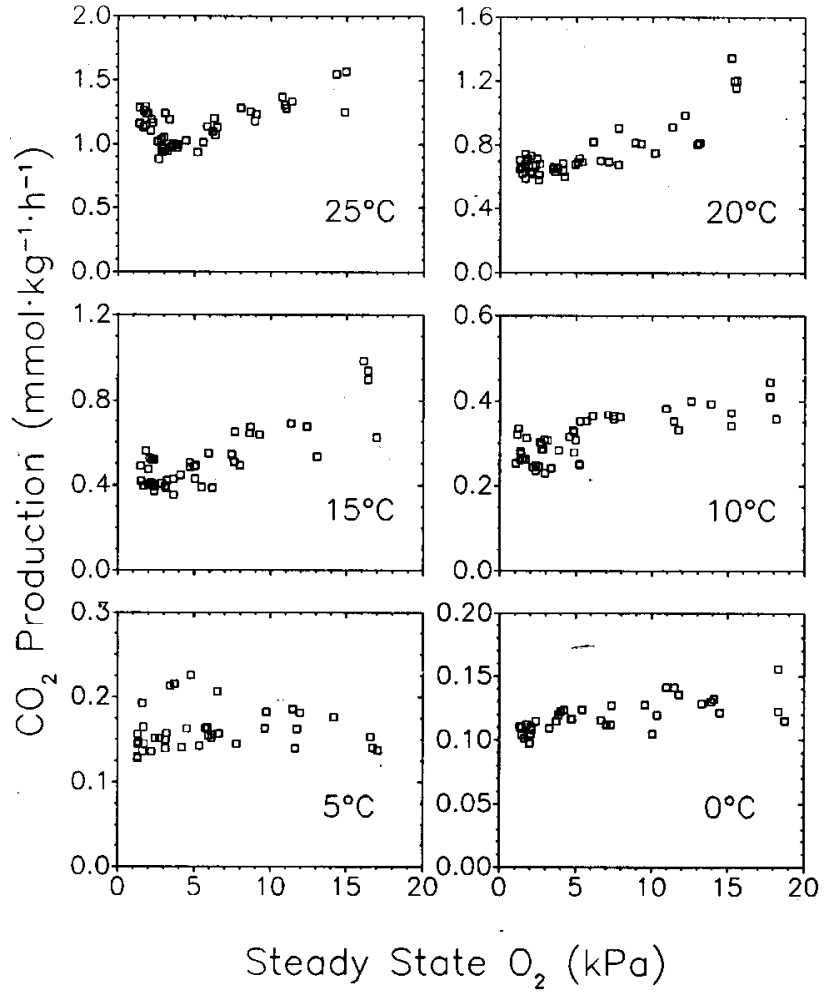

Fig. 5. Interdependent effects of steady-state $\mathrm{O}_{2}$ partial pressure and storage temperature on calculated rate of $\mathrm{CO}_{2}$ production of blueberry fruit in sealed LDPE packages.

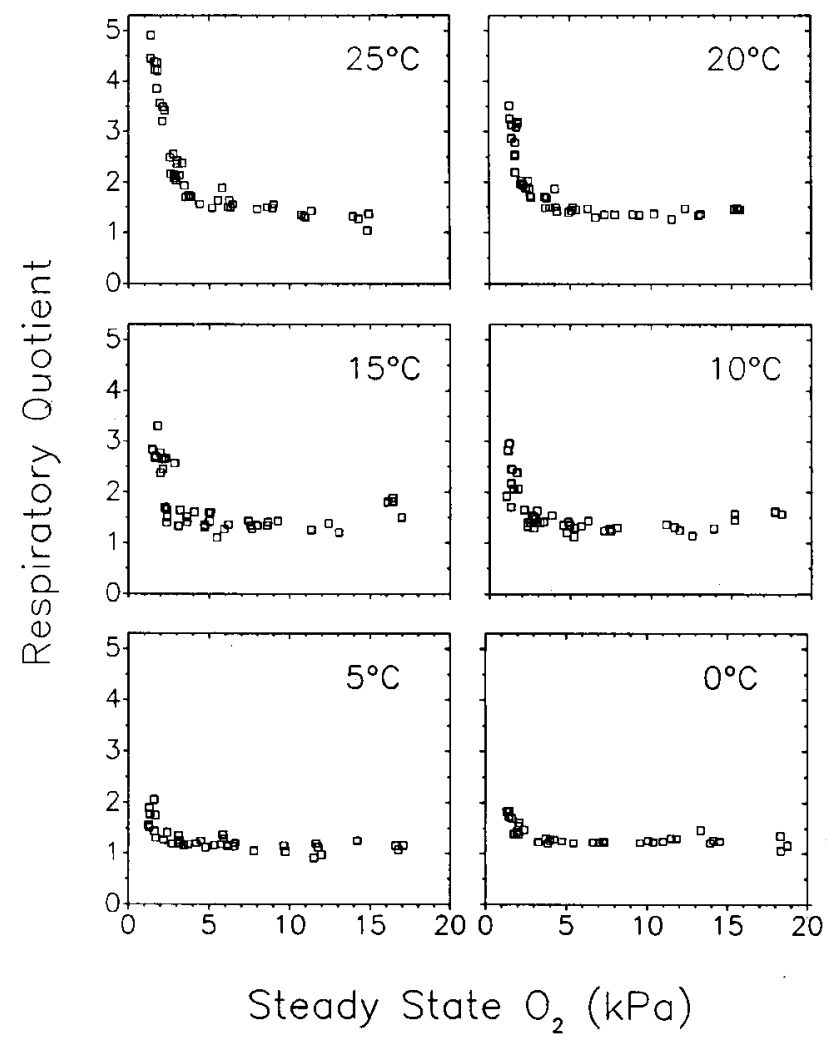

Fig. 6. Effect of steady-state $\mathrm{O}_{2}$ partial pressure on the respiratory quotient of blueberry fruit in sealed LDPE packages held at 0,5 , $10,15,20$, or $25 \mathrm{C}$. 
increased. Estimates of the $\mathrm{O}_{2}$ partial pressure at which the RQ breakpoint occurred were made from the graphs: $1.8 \mathrm{kPa}$ at $5 \mathrm{C}$; $2.0 \mathrm{kPa}$ at $10 \mathrm{C} ; 2.5 \mathrm{kPa}$ at $15 \mathrm{G} 3.0 \mathrm{kPa}$ at $20 \mathrm{C}$; and $4.0 \mathrm{kPa}$ at $25 \mathrm{C}$ (Figs. 3 and 6). Insufficient data were available to estimate the RQ breakpoint at OC, although it did not appear to be higher than for $5 \mathrm{C}$. The RQ at higher, aerobic $0_{2}$ partial pressures was $\approx 1.3$ for all temperatures.

\section{Discussion}

Storage temperature is known to affect the gaseous composition of MAP systems for various commodities (Kader et al., 1989), although in some cases the effect is rather minimal (Prince et al., 1986). It is recognized that steady-state $\mathrm{O}_{2}$ and $\mathrm{CO}_{2}$ levels depend on film permeability and product respiration and that the temperature dependence of these two processes is determined by film type, and commodity physiology, respectively. Additionally, suppression of respiration for some fruit takes place at $\mathrm{CO}_{2}$ levels above 10 to $20 \mathrm{kpa}$, but to our knowledge, this has not been documented for blueberry fruit. We therefore assumed respiration was minimally affected by levels of $\mathrm{CO}_{2}$ below the approximate $20 \mathrm{kPa}$ that accumulated in packages under hypoxic conditions. This assumption has since been verified (R.M.B., unpublished).

The safe range of $\mathrm{O}_{2}$ partial pressures needs to be identified for any product if a MAP system is to be used. One measure of the lower $\mathrm{O}_{2}$ partial pressure limit is the lowest $\mathrm{O}_{2}$ partial pressure that does not induce anaerobic $\mathrm{CO}_{2}$ production. Anaerobic respiration can be detected by the upswing in the RQ (the RQ breakpoint) associated with the synthesis of acetaldehyde, ethanol, and $\mathrm{CO}_{2}$. Although some degree of anaerobiosis can be tolerated (Cohen et al., 1990; Ke and Kader, 1990), there would be less risk if products were maintained at an $\mathrm{O}_{2}$ level higher than that associated with the RQ breakpoint. The $\mathrm{RQ}$ is easily calculated for fruit in MAP systems (Cameron, 1990; Cameron et al., 1989) and its breakpoint can be correlated with the package $0_{2}$ partial pressure. For blueberry fruit, we have assumed the lower limit for the storage $\mathrm{O}_{2}$ partial pressure to be that partial pressure associated with the RQ breakpoint.

The rise in the lower $\mathrm{O}_{2}$ limit with increasing temperature has not been previously reported. This observed change can be explained, at least in part, in terms of gas diffusion into the fruit. For many fruits, resistance to $\mathrm{O}_{2}$ movement into the tissues is highest at the skin (Burg and Burg, 1965; Cameron and Yang, 1982). We hypothesize that as temperature increased, the rate of $\mathrm{O}_{2}$ consumption by the tissue rose more rapidly than skin permeability to $\mathrm{O}_{2}$. For fruit with similar internal $\mathrm{O}_{2}$ levels (e.g., that internal $\mathrm{O}_{2}$ level which begins to induce fermentation), the $\mathrm{O}_{2}$ gradient across the skin would have increased as temperature increased, leading to the observed rise in steadystate $\mathrm{O}_{2}$ at the RQ breakpoint. The magnitude of the skin's permeability to either $\mathrm{O}_{2}$ or $\mathrm{CO}_{2}$ and the temperature sensitivity of these permeabilities are unknown.

The high RQ $(\approx 1.3)$ of aerobic fruit might be indicative of the oxidation of organic acids. Both organic acids (mostly citric acid) and sugars are plentiful in blueberry fruit, commonly reaching levels of $0.3 \%$ to $1.3 \%$ and $12 \%$ to $15 \%$, respectively (Eck, 1988).

The possibility of creating hypoxic environments within MAP systems during handling, transit, and storage is a serious concern for commercial enterprises interested in using MAP techniques, especially with regard to temperature fluctuations. The data indicate that a MAP system for blueberry fruit, designed to develop and maintain aerobic steady-state $\mathrm{O}_{2}$ partial pressures for storage temperatures ranging from 0 to $25 \mathrm{C}$, should maintain an $\mathrm{O}_{2}$ partial pressure at or above $\approx 4 \mathrm{kPa}$ at $25 \mathrm{C}$ and at or above $\approx 1.8 \mathrm{kPa}$ at $0 \mathrm{C}$. If the goal of MAP of blueberry fruit were to maintain these minimal $\mathrm{O}_{2}$ levels, then the LDPE film used here would not be appropriate. For example, when optimizing packages for storage at $0 \mathrm{C}$, about $110 \mathrm{~g}$ fruit weight per package achieved an $\mathrm{O}_{2}$ partial pressure near the lowest tolerable level of $\approx 1.8 \mathrm{kpa}$ (Fig. 3 ). These same 110 -g packages were clearly hypoxic at $25 \mathrm{C}$, the fruit having an RQ of $\approx 3$.

To maintain the lowest $0_{2}$ partial pressures tolerable at all temperatures for blueberry fruit would require a film whose $\mathrm{O}_{2}$ permeability would increase more rapidly with temperature than that of LDPE. In this experiment, the decline in steady-state $\mathrm{O}_{2}$ for a given fruit weight with increasing temperature indicated that $\mathrm{O}_{2}$ consumption was more sensitive to temperature than $\mathrm{O}_{2}$ permeation through the LDPE film. A film with a greater temperature sensitivity than LDPE would need to have an energy of activation for $\mathrm{O}_{2}$ permeability higher than the $40 \mathrm{~kJ} \cdot \mathrm{mol}$ for LDPE. To our knowledge, films with higher energies of activation for $\mathrm{O}_{2}$ permeation all have very low $\mathrm{O}_{2}$ permeability.

An enhancement of storage life of blueberry fruit by low $\mathrm{O}_{2}$ is open to question in that decay is often the primary determinant of blueberry fruit shelf life. Ceponis and Cappellini (1985) found that CA storage of highbush blueberry fruit at $2 \mathrm{kPa} \mathrm{O}_{2}$ and $2 \mathrm{C}$ did not effectively reduce the incidence of decay relative to air, nor did it enhance the effect of $\mathrm{CO}_{2}$ treatment. However, the storage period was relatively short (7 to 14 days) in comparison to the potential storage life of blueberry fruit (35 to 40 days) (Bunemann et al., 1957; Hruschka and Kushman, 1963). In other studies, storage of highbush blueberry fruit under low $\mathrm{O}_{2}$ (1.5 to $2 \mathrm{kPa}$ ) at nonfungistatic $\mathrm{CO}_{2}$ partial pressures suggests that low $\mathrm{O}_{2}$ was helpful in reducing the incidence of runny and decayed berries during long-term storage (5 to 7 weeks) (Frisina et al., 1988; D.L.D. and R. M. B., unpublished data; Dilley, unpublished data).

The methodology outlined here would be useful in defining the lower $0_{2}$ limits for numerous commodities. Furthermore, it can be used to generate the data necessary to establish film permeability characteristics needed for developing a working MAP system that would avoid anaerobic atmospheres. A model that can be used to specifically determine the needed temperature sensitivity of a film's $0_{2}$ permeability has been developed for blueberry fruit using these respiration data (A.C.C. and R. M. B., unpublished).

Developing a functional and practical MAP system for any perishable commodity requires that we understand how temperature affects film permeability characteristics, the respiratory processes of $\mathrm{O}_{2}$ consumption and $\mathrm{CO}_{2}$ production, and the lower $\mathrm{O}_{2}$ limit. Additional progress needs to be made in the areas of film manufacture, packing techniques, package construction, handling, and marketing to make MAP of blueberry or other commodities a viable alternative to either CA storage or the simple overwraps presently used.

\section{Literature Cited}

Boylan-Pett, W. 1986. Design and function of a modified atmosphere package for tomato fruit. MS Thesis, Michigan State Univ., East Lansing.

Bünemann, G., D.H. Dewey, and D.P. Watson. 1957. Anatomical changes in the fruit of Rubel blueberry during storage in controlled atmosphere. Proc. Amer. Soc. Hort. Sci. 70:156-160.

Burg, S.A. and E.A. Burg. 1965. Gas exchange in fruits. Physiol. Plant 18:870-884. 
Cameron, A.C. 1990. Modified atmosphere packaging: A novel approach for optimizing package oxygen and carbon dioxide. Proc. 5th Intl. CA Conf., 14-16 June 1990, Wenatchee, Wash.

Cameron, A. C., W. Boylan-Pett, and J. Lee. 1989. Design of modified atmosphere packaging systems: Modeling oxygen concentrations within sealed packages of tomato fruits. J. Food Sci. 54:1413-1416, 1421.

Cameron, A.C. and S.F. Yang. 1982. A simple method for the determination of resistance to gas diffusion in plant organs. Plant Physiol. 70:21-23.

Ceponis, M.J. and R.A. Cappellini. 1985. Reducing decay in fresh blueberries with controlled atmospheres. HortScience 20:228-229.

Cohen, E., Y. Shalom, and I. Rosenberger. 1990. Postharvest ethanol buildup and off-flavor in 'Murcott' tangerine fruits. J. Amer. Soc. Hort. Sci. 115:775-778.

Eck, P. 1988. Blueberry science. Rutgers Univ. Press, New Brunswick, N.J. p. 200-212.

Eisensmith, S.P. 1987. Plotit 5.0: Interactive graphics and statistics. Haslett, Mich.

Frisina, J., L. Barrand, C. Cooper, C. Little, and K. Clayton-Greene.
1988. Blueberry storage trials progress report for 1987/1988. Hort. Res. Inst., Knoxfield, Australia.

Hruschka, H.W. and L.J. Kushman. 1963. Storage and shelf-life of packaged blueberries. U.S. Dept. Agr. Mkt. Res. Rpt. 612.

Kader, A. A., D. Zagory, and E.L. KerbeL 1989. Modified atmosphere packaging of fruits and vegetables. Crit. Rev. Food Sci. Nutr. 28:130 .

Ke, D. and A.A. Kader. 1990. Tolerance of 'Valencia' oranges to controlled atmospheres as determined by physiological responses and quality attributes. J. Amer. Soc. Hort. Sci. 115:779-783.

Prince, T. A., R.C. Herner, and J. Lee. 1986. Bulb organ changes and influence of temperature on gaseous levels in a modified atmosphere package of precooled tulip bulbs. J. Amer. Soc. Hort. Sci. 111:900904.

Smittle, D.A. and W.R. Miller. 1988. Rabbiteye blueberry storage life and fruit quality in controlled atmospheres and air storage. J. Amer. Soc. Hort. Sci. 113:723-728.

Yasuda, H. and V. Stannett. 1975. Permeability coefficient, Sect. III p. 229-240. In: J. Brandup and E.H. Immergut (eds.). Polymer handbook. Wiley, New York. 